\title{
Microbial evaluation of some kinds of canned milk available in the markets of Al-Diwaniya city
}

\author{
H. H. H. H. Al-Fattly
}

Coll. of Pharmacy/Univ. of Al- Qadisiya

email: hamshussainhashim@Gmail.com

\section{Abstract}

This study aimed to compare bacterial contamination indicators such as (total bacterial count, total coliform count and faecal coliform count) for some canned milk belonging to different origins (Iraq, Syria, Jordan, Kuwait, and Saudi) available in the markets of Diwaniya city, in comparison with standards parameters and determine the validity of these products for human consumption. Through the results of the current study observed that Kuwaiti canned milk was a high bacterial count $\left(62 \times 10^{\wedge}{ }_{4}\right)$ CFUlml, followed by Syrian canned milk $(54 \times$ $\left.10^{\wedge} 4\right)$ CFUlml and Jordan milk $\left(52 \times 10^{\wedge} 4\right)$ CFUlml and Saudi milk with bacterial content $\left(53 \times 10^{\wedge} 4\right) \mathrm{CFU} \backslash \mathrm{ml},\left(51 \times 10^{\wedge}{ }_{4}\right) \mathrm{CFU} \backslash \mathrm{ml}$ and $\left(50 \times 10^{\wedge} 4\right) \mathrm{CFU} \backslash \mathrm{ml}$, respectively, to three types of Saudi canned milk, as for the Iraqi local milk has the amount of bacterial count $(42 \times$ $10^{\wedge} 4$ ) CFUlml. Isolation and Identification of contaminated bacteria include (Staphylococcus aureus, Bacillus spp., Klebsiella. pneumonia, Escherichia coli, Enterobacter spp., Pseudomonas aeruginosa). Through these indicators, the samples of imported milk was above the standard level of contamination and therefore out the standard of health, either the local milk it contains a less proportion of contamination from the importer, this was due to being produced locally and thus the short period of storage and quick access to the consumer.

Key words: canned milk, bacteria, CFUlml, contamination, local milk, imported milk

$$
\begin{aligned}
& \text { التقييم الميكروبي لبعض انواع الحليب المعلب المتوفر في اسواق مدينة } \\
& \text { الايو انية الحين } \\
& \text { همس حسين هاشم هندول الفتلي } \\
& \text { جامعة القادية \كلية الصيدلة الفيلة }
\end{aligned}
$$

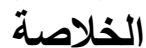

$$
\begin{aligned}
& \text { هدفت هذه الدر اسة الى مقارنة مؤشرات التلوث البكتيري ( العدد البكتيري الكلي , بكتريا القولون الكلية و البكتريا }
\end{aligned}
$$

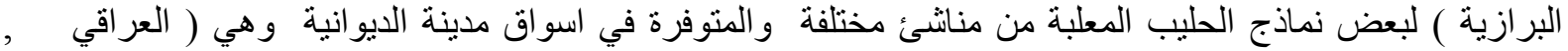

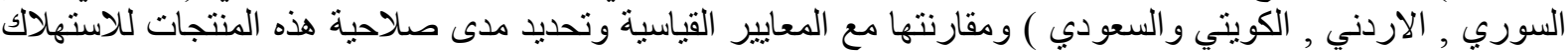

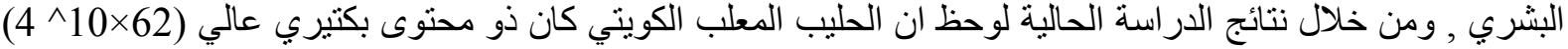

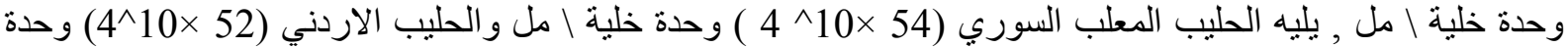

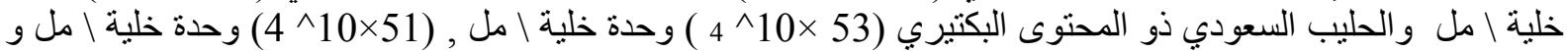

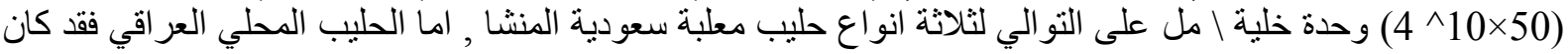

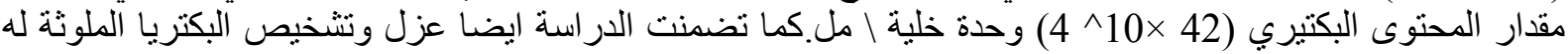

$$
\begin{aligned}
& \text { و و التي شملت: } \\
& \text { قصر فترة التخزين وسر عة الوصول الى المستهلك الكئ }
\end{aligned}
$$

\section{Introduction}

Milk plays a very important role in human life, primarily as a source of perfect food. Owing to their high availability and buffer properties and have nearly occupied a significant position in the feeding style, but is also an efficient vehicle for transmission of diseases to humans. Pathogenic bacteria pose a serious threat to human health, and constitute about $90 \%$ of all dairy-related 
diseases (1).Milk is nearly complete food because it contains most of the essential nutrients and almost ideal quantities needed by the human body, and milk is characterized by containing milk sugar Lactose is the only source of mono sugar (galactose) Gelatos which is one of the most important components of nerve tissue. And better benefit the body is milk product in the same environment in which they live rights. The milk exposure to microbes contaminations from the cows until reach to consumers whether a raw milk or its products, and the natural contents of proteolytic, lipolytic and toxic produced bacteria, such as Pseudomonas, Alcaligenes, Micrococcus, Salmonella, Bacillus and Staphylococcus (2). The components of milk and its physical and chemical properties provide a very favorable milieu for the multiplication of microorganisms (3). The warm and rather humid climatic conditions that prevail in most tropical countries) would tend to support the survival and growth of many microorganisms in milk (4), and Iraq is one of them. Recent studies have been established the emergence of new milk-borne bacterial pathogens such as Escherichia coli with more serious challenges for public health and the dairy industry. E. coli is responsible for several outbreaks of diarrhea in children and adults after ingestion of contaminated milk and dairy products (5). Different studies show that $1-5 \%$ of foodborne infections were related to consumption of milk and dairy products, that $53 \%$ of cases of food-borne infections caused by contaminated cheese and that enteropathogenic $E$. coli is the causative agent of $18.33 \%$ of these cases (6). The Staphylococcus spp. was the predominant organism isolated with the majority of them being Staph. aureus, the contamination presumably coming from the hands of the cheese-sellers. However, cows may excrete Staph. aureus from the udder, often without clinical evidence of mastitis (8). In Iraq, milk, cheese and cream were two of the important dairy products, but little percentage $(10 \%)$, were make in a hygienic conditions in large dairy factory, when the large percentage were make in unhygienic conditions whether in a dairy factory or houses or shops (9). Yoghurt defects due to microbial contamination and the most frequent contaminants are yeasts and moulds (10). The aim of this study was to determine bacterial contaminated of canned milk from different origins that circulation in ALDiwaniya markets and investigation from its validity to consumption.

\section{Materials and methods}

A total of 70 canned samples of milk were collected randomly from the Markets, from different origins (Iraqi, Jordan, Syrian, Saudi and Kuwaiti), during the period of the mid of October 2012 to the mid of February 2013. The samples were transported to the laboratory for microbiological analysis. Samples of milk were processed as follows: In a $10 \mathrm{ml}$ marked tube, $1 \mathrm{ml}$ of canned milk, were added to $9 \mathrm{ml}$ of sterile water by pipette and then repeat the process to take $1 \mathrm{ml}$ of a sample of milk.

-Take from the first tube $1 \mathrm{ml}$ and added to the second tube and so we get dilutions 1\100, 1\1000, 1\10000, 1\100000.

-Take $1 \mathrm{ml}$ of all dilutions in Petri dishes and pour the nutrient agar media on it, then incubated at $22{ }^{\circ} \mathrm{C}$ and $35{ }^{\circ} \mathrm{C}$ for $24 \mathrm{hrs}$.

-Total and fecal coliform count determined by pour plate count by taking $1 \mathrm{ml}$ of all dilutions in Petri dishes and pour the then inoculated on violet red bile agar, later the first incubated at $37 . \mathrm{C}$ for $24 \mathrm{hrs}$ and the second incubated at $44.5 \cdot \mathrm{C}$ for $48 \mathrm{hrs}$ (11).

-The growth colonies were counted by colonies counter, numbers of bacteria exist by multiply of colonies number by dilution reverse and all microbiological tests were performed in triplicate.

-The growth bacteria was isolated, then examined and diagnosed according to biochemical, morphological characterizations as well as standard methylene blue reduction and resozarin tests were done $(12,13,14$, and 15).

\section{Results}

In present study, the results revealed that the total aerobic bacterial count obtained from Kuwaiti canned milk accomplished $\left(62 \times 10^{\wedge} 4\right) \mathrm{cfu} / \mathrm{ml}$, whereas quite empty from any faecal coliform bacteria. The total aerobic bacterial count obtained from Syrian 
canned milk accomplished $\left(54 \times 10^{\wedge} 4\right) \mathrm{cfu} / \mathrm{ml}$, whereas the rates of total coliform bacteria count $\left(11 \times 10^{\wedge} 2\right) \mathrm{cfu} / \mathrm{ml}$, and also the Faecal coliform bacteria from it in rate $\left(7 \times 10^{\wedge} 2\right)$ $\mathrm{cfu} / \mathrm{ml}$. The total aerobic bacterial count obtained from Saudi canned milk accomplished $\left(53 \times 10^{\wedge} 4\right) \mathrm{cfu} / \mathrm{ml},\left(51 \times 10^{\wedge} 4\right)$ $\mathrm{cfu} / \mathrm{ml}$ and (50x10^4) $\mathrm{cfu} / \mathrm{ml}$ respectively and quite empty from any faecal coliform bacteria, The total aerobic bacterial count obtained from Jordan canned milk accomplished $\left(52 \times 10^{\wedge} 4\right) \mathrm{cfu} / \mathrm{ml}$, whereas the rates of total coliform bacteria count (14 $\times 10^{\wedge}$ ) $\mathrm{cfu} / \mathrm{ml}$, and also the Faecal coliform bacteria from it in rate $\left(9 \times 10^{\wedge} 2\right) \mathrm{cfu} / \mathrm{ml}$. The total aerobic bacterial count obtained from Iraqi canned milk accomplished $\left(42 \times 10^{\wedge} 4\right)$ $\mathrm{cfu} / \mathrm{ml}$, whereas the rates of total coliform bacteria count $\left(2 \times 10^{\wedge} 2\right) \mathrm{cfu} / \mathrm{ml}$. , Table, 1 .

\section{Table (1): Total bacterial count in canned milk from different origins which circulation} in AL-Diwaniya markets.

\begin{tabular}{|c|c|c|c|c|}
\hline \multirow{7}{*}{ Sample } & Origin & Total bacteria count & $\begin{array}{c}\text { Total coliform } \\
\text { bacteria } \\
\text { CFUlml }\end{array}$ & $\begin{array}{c}\text { Fecal coliform } \\
\text { bacteria } \\
\text { CFUlml }\end{array}$ \\
\hline \multirow{5}{*}{ Canned milk } & Iraqi & $42 \times 10^{\wedge} 4$ & $2 \times 10^{\wedge} 2$ & - \\
\cline { 2 - 5 } & Jordan & $52 \times 10^{\wedge} 4$ & $14 \times 10^{\wedge} 2$ & $9 \times 10^{\wedge} 2$ \\
\cline { 2 - 5 } & Syrian & $54 \times 10^{\wedge} 4$ & $11 \times 10^{\wedge} 2$ & $7 \times 10^{\wedge} 2$ \\
\cline { 2 - 5 } & Saudi -1 & $51 \times 10^{\wedge} 4$ & - & - \\
\cline { 2 - 5 } & Saudi -2 & $50 \times 10^{\wedge} 4$ & - & - \\
\cline { 2 - 5 } & Saudi -3 & $53 \times 10^{\wedge} 4$ & - & - \\
\cline { 2 - 5 } & Kuwaiti & $62 \times 10^{\wedge} 4$ & - & - \\
\hline
\end{tabular}

On the other hand, this study included the detection of some genus and species of bacteria in canned milk (Table 2). Staphylococcus aureus was isolated and identified from all origin of canned milk, and Bacillus spp. was isolated and identified from the canned milk of Jordan and Syrian origin only, Klebsiella pneumonia was isolated and identified from the Jordan canned milk only, E. coli was isolated and identified from all origin of canned milk except Kuwaiti (KDD) wasn't isolate this bacteria from it, Enterobacter sp. And Ps. aeruginosa was isolated and identified from canned milk of Jordan and Syrian origin only.

Table (2): Some of isolated bacteria from canned milk from different origins circulation in AL-Diwaniya markets.

\begin{tabular}{|c|c|c|c|c|c|c|c|}
\hline \multirow{2}{*}{ Sample } & Origin & $\begin{array}{c}\text { Staphylococcus } \\
\text { aureus }\end{array}$ & $\begin{array}{c}\text { Bacillus } \\
\text { sp. }\end{array}$ & $\begin{array}{c}\text { K. } \\
\text { pneumonia }\end{array}$ & $\begin{array}{c}\text { E. } \\
\text { coli }\end{array}$ & $\begin{array}{c}\text { Enterobacter } \\
\text { sp. }\end{array}$ & $\begin{array}{c}\text { Ps. } \\
\text { aeruginosa }\end{array}$ \\
\hline \multirow{4}{*}{ Milk } & Iraqi & + & - & - & + & - & - \\
\cline { 2 - 8 } & Jordan & + & + & + & + & + & + \\
\cline { 2 - 8 } & Syrian & + & + & - & + & + & + \\
\cline { 2 - 8 } & Saudi & + & - & - & + & - & - \\
\cline { 2 - 8 } & Kuwaiti & + & - & - & - & - & - \\
\hline
\end{tabular}

\section{Discussion}

All kinds of imported milk that have been studied were more than the standard specifications of hygienic parameters and which provides for the microbial load does not exceed up to $(5 \times 105) \mathrm{cfu} / \mathrm{ml}$ of pasteurized milk and not to exceed coliform bacteria up to $10 / \mathrm{ml}$ of milk(New York State milk standards) (16). (17).. This results were agreement with study (18) that indicate to increase total aerobic bacterial count in milk, The total aerobic bacterial count obtained from Iraqi canned milk accomplished $\left(42 \times 10^{\wedge}\right) \mathrm{cfu} / \mathrm{ml}$, whereas the rates of total coliform bacteria count $\left(2 \times 10^{\wedge} 2\right) \mathrm{cfu} / \mathrm{ml}$, therefore it was not agreement with standard specifications but it contains a less proportion of contamination from the importer this was due to being produced locally and thus the short period of storage 
and quick access to the consumer.. This result was agreement with study that indicate to increase total aerobic bacterial count in canned milk (19) Table, 1. The results found are manifested in the (Table, 1) revealed an increase in faecal coliform bacterial count with rates $(14 \times 102) \mathrm{cfu} / \mathrm{ml}$ and $(11 \times 102)$ $\mathrm{cfu} / \mathrm{ml}$ in canned milk samples for Jordan and Iraqi milk respectively, the presence of this bacteria may refers to faecal contamination. The cause of high bacterial contamination of canned samples of milk may be return to absence of hygienic conditions during Trading and processing, they are also associated to storage temperature of milk without refrigeration, un pasteurization of milk, circulation and transportation (20). Coliform have significance in milk because they are easily killed during pasteurization and because they are generally regarded to originate from the intestinal tract of warmblooded animals. Hence, the presence of coliform bacteria in canned milk products is suggest of unsanitary conditions or practices during processing; In the past, Coliforms have been used as an indicator for pathogens, but they are no longer recommended for this purpose due to the fact that coliform organisms are present as normal inhabitants of soil and water, not just specifically from faecal contamination. Some people may wonder if there is co-relationship between the presence of pathogenic bacteria from faecal source, especially Salmonella and Shigella species, and the presence of Coliforms. As mentioned before, Coliforms are not specific enough for that purpose and it is important to note that these two bacterial species are not Coliforms. In the milk sample concerned, coliform organisms were detected, but it does not necessarily mean that there were pathogenic bacteria. Presence of Coliforms means there may have been problems in the efficiency of heat treatment or re-contamination after heat treatment. In these cases, the food manufacturer is required to check for process failure and ensure product safety (19). Coliforms, which are often used to monitor the quality of milk, are not a single species of organism. They are a group of gram negative rod-shaped bacteria that have similar biochemical characteristics - being able to ferment lactose with the production of acid and gas within 48 hours at $35^{\circ} \mathrm{C}$ and grow with or without oxygen. They are usually present in small number in raw milk, meat, poultry or other raw foods. Coliforms count is simple and easy to conduct; hence it can be used as a hygienic indicator to reflect the general microbiological quality in routine test. As coliform organisms can be easily killed by heat, these bacteria can also be used as an indicator of heat treatment failure as well as post heat treatment contamination (19). Staphylococcus aureus was isolated and identified from all origin of canned milk, and Bacillus spp., Enterobacter sp. and Ps. aeruginosa isolated from Syrian and Jordan canned milk, probably these bacteria may be responsible for cases of acute gastrointestinal infections, due to Enterotoxin (21), Thus, Bacillus spp. is able to produce spores, which can survive pasteurization( 8). Klebsiella pneumonia was isolated from milk, this contamination attributed to internal and external sources because of it was resistance to dryness on skin and equipments so, its regard one of causatives cross-infection (22). The results showed that the canned milk was contaminated with E. coli bacteria. The occurrence of a high proportion of $E$. coli in milk samples may be due to lack of proper sanitation and absence of pasteurization of milk. Therefore, stringent hygienic measures must be followed and pasteurization of milk should be imposed to prevent contamination of milk with Coliforms. Otherwise, this traditional milk should be collected from the market(20).

\section{References}

1.Ryser, E.T. (1998). Public Health Concerns. In: Applied Dairy Microbiology; Steele Edition. Mercell Dekker, Inc New York. 263-404.

2.Garbutt, J. (1997). Essentials of food microbiology. Arnold, member of the hotter headline group. London, U.K. Pp: 128-236.

3.Hanak, E.; Boutrif, E.; Fabre, P. \& Pineiro, M. (2002). Food Safety Management in Developing Countries. Proceedings of the International Workshop, CIRAD-FAO, 11-13 December 2000, Montpellier, France, CIRAD-FAO. CIRAD CDROM, Montpellier, France. 
4.Bos, C.E. Van Doorne, H. \& OLerk, C.F. (1989). Microbiological stability of tablets stored under Tropical conditions. Inter. J. Pharm. 55: 175-83.

5.Schrade, J.P. \& Yager, J. (2001). Implication of milk and milk products in food disease in France and in different industrialized countries. Int. J. Food Microbiol. 67: 1-17.

6.Sivapalasingams, S.; Friedman, C.R.; Cohen, L. \& Tauxe, R.V. (2004). Fresh produce: a growing cause of outbreaks of food borne illness in the United States. J. Food Protect. 67(10): 2342-2353.

7.Vasavanda, P.C.; Cousin, M.A. (1992). Dairy microbiology and safety. In: Hui Y.H. Dairy science and technology hand book. Vol. 2. New York, federal Republic of Germany, UK: (Product Manufacturing. VCH-Publishers;. pp. 330-360.

8.Vaishnavi, C.; Singh, S.; Grover, R. \& Singh, K. (2001). Bacteriological study of Indian cheese (paneer) sold in Chandigarh. Vol. 19. 4: 224-226.

9.Abdulla, S.M. \& Musleh, R.M. (1988). Bacterial contamination of soft white cheese and cheeserocessing plant with special reference to psychrophytic Pseudomonads. J. Bio. Sci. 19(1): 1-12.

10. Fleet, G.H. \& Mian, M.A. (1987). The occurrence and growth of yeasts in dairy products. Int. J. Food Microbiol. 4:145-155.

11. WHO (World Health Organization). (1997). Guideline for drinking water quality. 2nd ed. Vol. 2. Geneva.

12. Holt, J.G.; Krieg, N.R.; Sneath, P.H.; Staley, J.T. \& William, S.T. (1994). Berger's manual of determinative bacteriology. 9th ed. Lippin Cott William and Wilkins. Baltimore, USA.
13. Collee, J.G.; Fraser, A.G.; Marmion, B.P. \& Simmons, A. (1996).Practical medical microbiology. 14th ed. Churchill Living stone. Inc. New York, USA.

14. Stukus, P.E. (1997). Investigating microbiology: A Laboratory manual for general microbiology. Harcourt brace and Company. Philadelphia, USA. Pp: 169-467.

15. Macfaddin, J.F. (1979). Biochemical tests for Identifications of medical bacteria. 3rd ed. Lippin Cott Williams and Wilkins. Philadelphia, USA.

16. American Public Health Association(APHA) .(1997). Sampling Dairy. And related products. Standard methods for examination of Dairy products, Washington, USA.

17. Nickerson, J.T. \& Sinskey, A. J. (1972). Microbiology of food \& food processing. A. M. Elesvier publishing Comp. New York.

18. AL-Kuzaiy, O.M. (2006). Microbial and chemical evaluation for milk and some its products in diwanyia city. M.SC. thesis, college of veterinary medicine. University of AL-Qadisiaya .

19. Chong, K. (2008). Coliforms in milk - Presence of Bad Bugs .food safety focus.24th Issue, July 2008. Incident in focus center for food safety.

20. Najad, L.M. \& Ghanbarpour, R. (2006). Study on enteropathogenic Escherichia coli isolated from domestic Iranian soft cheese 76 (6); 531-536.

21. Rollins, D.M. (2000). Enterobateriaecae summary. B. Sc. 124. Pathogenic microbiology fall 2000.

22. Case well, M.W. \& Desai, N. (1983). Survivals of multiply resistant Klebsiella pneumonia and other Gram-negative bacteria on finger-tip. J. of Hospital. 4: 350-360. 